\title{
INABILITY OF HISTAMINE TO INDUCE DECIDUOMATA IN PREGNANT AND PSEUDOPREGNANT RATS*
}

\author{
UPENDRA K. BANIK AND MELVIN M. KETCHEL
}

Worcester Foundation for Experimental Biology, Shrewsbury, Massachusetts, U.S.A.

(Received 19th November 1963)

According to a proposal by Shelesnyak $(1957,1960)$, histamine is the chemical stimulus which causes deciduoma formation. Subsequent studies have also indicated that histamine is involved in the decidual reaction (cf. Marcus, Kraicer \& Shelesnyak, 1963; Kracier, Marcus \& Shelesnyak, 1963). A student laboratory manual, in an experiment to demonstrate the formation of deciduomata, specifies the use of histamine (Zarrow, 1960). However, in our experience histamine does not produce deciduomata in rats made pseudopregnant by sterile matings. Also, Finn \& Keen (1962), using rats made pseudopregnant by electrical stimulation of the cervix, were unable to cause decidual reactions with histamine injections. Orsini (1963) was unable to produce decidual reactions in either the rat or the hamster with systemic injections of pyrathiazine, a histamine-releasing agent. Further, Banik, Kobayashi \& Ketchel (1963) have shown that increasing or decreasing the histamine level in rats had no effect on nidation. In view of the many conflicting reports, we have reinvestigated the effect of intrauterine injections of histamine on the induction of deciduomata, using pregnant, pseudopregnant and nonpregnant rats.

Adult female Sprague-Dawley rats weighing 200 to $250 \mathrm{~g}$ were placed in mating cages in the evening with normal males to obtain pregnant females, or with vasectomized males to obtain pseudopregnant females. Pregnancy or pseudopregnancy was ascertained by the presence of a vaginal plug early the following day, which was designated Day 1 . Dioestrous or oestrous females were obtained by vaginal smears taken through at least two consecutive normal oestrous cycles.

Histamine dihydrochloride was dissolved in $0.85 \% \mathrm{NaCl}$ and $0.1 \mathrm{ml}$ was injected very carefully into the left uterine horn near the uterotubal junction with a hypodermic needle (No. 30 s.w.g.). An equal volume of $0.85 \% \mathrm{NaCl}$ solution was injected into the right uterine horn. For mechanical trauma experiments, 2-0 surgical thread was inserted into the left horn of the uterus from a point near the uterotubal junction to a point near the cervix. Pregnant or pseudopregnant rats were injected with histamine or saline or had the thread inserted on Day 5 of pregnancy or pseudopregnancy and were killed on Day 8. Oestrous and dioestrous rats were treated with histamine, saline, or thread

* Work supported by Grant HD-00624-01 from the National Institute of Child Health and Human Development, Department of Health, Education and Welfare. 
when they were found to be at the appropriate stages, and were killed $72 \mathrm{hr}$ afterwards. At autopsy the uterine horns were dissected free of adherent tissue and weighed individually. The weights of the uterine horns are expressed as

TABLE 1

INDUCTION OF DECIDUOMATA IN PREGNANT, PSEUDOPREGNANT AND NON-PREGNANT RATS

\begin{tabular}{|c|c|c|c|c|c|c|}
\hline \multirow[b]{2}{*}{ Group } & \multirow{2}{*}{$\begin{array}{c}\text { Status of } \\
\text { animal }\end{array}$} & \multirow[b]{2}{*}{ Treatment } & \multirow{2}{*}{$\begin{array}{l}\text { No. } \\
\text { rats }\end{array}$} & \multicolumn{2}{|c|}{ Uterine wt. per $100 \mathrm{~g}$ body wt. $(\mathrm{mg})$} & \multirow{2}{*}{$P^{*}$} \\
\hline & & & & $\begin{array}{c}\text { Left hom }(\text { L.H. }) \\
(\text { Mean } \pm \text { S.E. })\end{array}$ & $\begin{array}{l}\text { Right horn }(\text { R.H. }) \\
(\text { Mean } \pm \text { S.E. })\end{array}$ & \\
\hline 1 & Pregnant & $\begin{array}{l}\text { Histamine } \\
250 \text { mg to L.H. } \\
\text { Saline to R.H. }\end{array}$ & 15 & $123 \cdot 68 \pm 16 \cdot 5$ & $115 \cdot 72 \pm 15 \cdot 6$ & ns $\dagger$ \\
\hline 2 & Pregnant & $\begin{array}{l}\text { Histamine } \\
500 \mu g \text { to L.H. } \\
\text { Saline to R.H. }\end{array}$ & 6 & $110.01 \pm 11.7$ & $123 \cdot 73 \pm 24 \cdot 4$ & Ns \\
\hline 3 & Pregnant & $\begin{array}{l}\text { Histamine } \\
2 \mathrm{mg} \text { to L.H. } \\
\text { Saline to R.H. }\end{array}$ & 12 & $102 \cdot 17 \pm 6 \cdot 78$ & $104 \cdot 57 \pm 9 \cdot 17$ & NS \\
\hline 4 & Pregnant & $\begin{array}{l}\text { Thread to L.H. } \\
\text { Nothing to R.H. }\end{array}$ & 6 & $257 \cdot 71 \pm 13 \cdot 62$ & $113 \cdot 76 \pm 10 \cdot 44$ & $<0.001$ \\
\hline 5 & $\begin{array}{l}\text { Pseudo- } \\
\text { pregnant }\end{array}$ & $\begin{array}{l}\text { Histamine } \\
250 \mu \mathrm{g} \text { to } \mathrm{L.H} \text {. } \\
\text { Saline to R.H. }\end{array}$ & 7 & $103.96 \pm 21.95$ & $82 \cdot 31 \pm 11 \cdot 8$ & NS \\
\hline 6 & $\begin{array}{l}\text { Pseudo- } \\
\text { pregnant }\end{array}$ & $\begin{array}{l}\text { Histamine } \\
500 \text { ug to L.H. } \\
\text { Saline to R.H. }\end{array}$ & 10 & $114 \cdot 41 \pm 24 \cdot 1$ & $78 \cdot 64 \pm 7 \cdot 6$ & NS \\
\hline 7 & $\begin{array}{l}\text { Pseudo- } \\
\text { pregnant }\end{array}$ & $\begin{array}{l}\text { Histamine } \\
2 \mathrm{mg} \text { to L.H. } \\
\text { Saline to R.H. }\end{array}$ & 13 & $106 \cdot 87 \pm 13 \cdot 42$ & $121 \cdot 05 \pm 11 \cdot 64$ & NS \\
\hline 8 & $\begin{array}{l}\text { Pseudo- } \\
\text { pregnant }\end{array}$ & $\begin{array}{l}\text { Thread to L.H. } \\
\text { Nothing to R.H. }\end{array}$ & 8 & $249 \cdot 10 \pm 10 \cdot 96$ & $66 \cdot 02 \pm 2 \cdot 64$ & $<0.001$ \\
\hline 9 & Dioestrous & $\begin{array}{l}\text { Histamine }+ \text { to } L . H . \\
\text { Saline to R.H. }\end{array}$ & 7 & $78 \cdot 45 \pm 7 \cdot 36$ & $81.50 \pm 8.01$ & Ns $\dagger$ \\
\hline 10 & Dioestrous & $\begin{array}{l}\text { Thread to L.H. } \\
\text { Nothing to R.H. }\end{array}$ & 6 & $166 \cdot 30 \pm 27 \cdot 58$ & $98.46 \pm 11.93$ & $<0.05$ \\
\hline 11 & Oestrous & $\begin{array}{l}\text { Histamine } \text { to } \mathbf{L . H} \text {. } \\
\text { Saline to R.H. }\end{array}$ & 6 & $78 \cdot 26 \pm 5 \cdot 13$ & $81 \cdot 40 \pm 6 \cdot 42$ & NS \\
\hline 12 & Oestrous & $\begin{array}{l}\text { Thread to L.H. } \\
\text { Nothing to R.H. }\end{array}$ & 4 & $151 \cdot 46 \pm 9 \cdot 73$ & $78 \cdot 87 \pm 6 \cdot 22$ & $<0.001$ \\
\hline
\end{tabular}

* Comparison between left and right horn.

$\dagger$ Not significantly different at $5 \%$ level.

$\$ 2 \mathrm{mg}$ of histamine of hydrochloride to left horn and $0.1 \mathrm{ml}$ of normal saline to right horn.

mg uterine horn per $100 \mathrm{~g}$ body weight. Students' $t$ test was used for statistical comparisons.

The effect of intrauterine injections of histamine dihydrochloride is shown in Table 1. Doses of histamine ranging from $250 \mathrm{\mu g}$ to $2 \mathrm{mg}$ did not cause significant increases in uterine horn weight in either pregnant (Groups 1, 2 and 3) or 
pseudopregnant (Groups 5, 6 and 7) rats when compared to injections of equal volumes of saline. In contrast, the induction of deciduomata was unequivocally demonstrated in pregnant and pseudopregnant rats by the implantation of thread (Groups 4 and 8 ). Histamine in doses of $2 \mathrm{mg}$ did not cause significant increases in the uterine horn weight of dioestrous (Group 9) or oestrous (Group 11) rats, whereas the implantation of a thread caused some increase in weight (Groups 10 and 12).

It is interesting to note the effect of the treatment on the implantation of ova. In uterine horns injected with either histamine or saline (Groups 1, 2 and 3), no implantation occurred. In Group 4 no implantation sites were observed in the uterine horns in which thread was inserted, although implantation did occur in the untreated control uterine horns. At the termination of the experiment (Day 8 of pregnancy), the implantation sites in Group 4 had not yet developed to a size that significantly affected the weight of the uterus. The weight of the untreated uterine horns therefore includes the weight of the conceptuses.

In some of our early experiments involving histamine, we observed that the injection of histamine into the uterus with a No. 25 needle did cause uterine swelling. However, as our technique of injecting and handling the uterus improved and we used No. 30 needles, this apparently non-specific trauma did not occur.

Recently, Cecil, Wrenn \& Bitman (1962) have shown that the response to injury and inflammation resulting in the decidual reaction was accompanied by an increase in histamine concentration, and that the decidual-growth-response resulted in a decrease in histamine concentration. The present data show that a rat uterus capable of responding to mechanical stimulation does not respond to exogenous histamine in large amounts, a finding in agreement with that of Finn \& Keen (1962). Kahlson (1962) has suggested that histamine is involved in the cellular metabolism concerned with growth and proliferation. We suggest that the changes in histamine concentration which occur in the uterus at the time of the decidual response do not cause the decidual response, but are related to the proliferative activity of the cells. The present evidence does not indicate that histamine liberation per se in a responsive uterus results in deciduoma formation.

\section{REFERENCES}

Banik, U. K., Kobayashi, Y. \& Ketchel, M. M. (1963) Effect of aminoguanidine, histamine, histidine and Compound 48/80 on pregnancy of rats and mice. 7. Reprod. Fertil. 6, 179.

Gecil, H. G., Wrenn, T. R. \& Bitman, J. (1962) Uterine histamine in rat deciduomata. Endocrinology, 71,960 .

Finn, C. A. \& KeEn, P. M. (1962) Failure of histamine to induce deciduomata in the rat. Nature, Lond. 194,602 .

Kahlson, G. (1962) New approaches to the physiology of histamine. Perspect. Biol. Med. 5, 179.

Kraicer, P. F., Marcus, G. J. \& Shelesnyak, M. C. (1963) Studies on the mechanism of decidualization. III. Decidualization in the histamine-depleted rat. 7. Reprod. Fertil. 5, 417.

Marcus, G. J., Kraicer, P. F. \& Shelesnyak, M. C. (1963) Studies on the mechanism of decidualization. II. Histamine-releasing action of pyrathiazine. 7. Reprod. Fertil. 5, 409.

Orsini, M. W. (1963) Attempted decidualization in the hamster and rat with pyrathiazine. 7. Reprod. Fertil. 5, 323.

Shelesnyak, M. C. (1957) Some experimental studies on the mechanism of ova-implantation in rat. Recent Progr. Hormone Res. 13, 269.

Shelesnyak, M. C. (1960) Nidation of the fertilized ovum. Endeavour, 19, 81.

Zarrow, M. X. (1960) A source book of experiments in endocrinology, p. 23. Purdue University Press, Lafayette. 